\title{
Lexical Ambiguity on Haninpost (한인포스) Newspaper Advertisements
}

\author{
Nadhifah Salsabila*, Didi Sukyadi, Risa Triarisanti \\ Universitas Pendidikan Indonesia, Bandung \\ *Corresponding author. Email: nadhifah230@gmail.com
}

\begin{abstract}
This research aims is to determine (1) lexical ambiguity in Haninpost newspaper advertisements (한인포스트) and the meaning contained in these lexical ambiguities and (2) the cause of lexical ambiguity in Haninpost newspaper advertisements. This research is motivated by the possibility of misinterpretation of the message conveyed by an author of advertisements in the language of advertisements. For a native speaker of Korean can immediately understand the message conveyed in the advertisement. Unlike the case with Korean language learners who do not necessarily understand all the words written in the advertisements because the message conveyed is ambiguous. This study used descriptive qualitative method. Data collection techniques used in this research are literature study and documentation studies. Data analysis techniques using an interactive model from Miles \& Huberman (1984), namely data collection, data reduction, data display, conclusion drawing and verification. The validity of the data uses data triangulation using the theories of Ullmann (1972), Yoon Pyeong Hyeon (2008), Han Jae Yeong, et al (2013), and Kim Ji Hyeong \& Lee Min Woo (2015). The results showed that the lexical ambiguity that exists in Haninpost newspaper advertisements is $27,27 \%$ consisting of local ambiguity and global ambiguity, as well as the causal factor for the meaning of lexical ambiguity is due to the relation of meaning which consists of polysemy and homonymy.
\end{abstract}

Keywords: Lexical ambiguity, cause of lexical ambiguity, advertisement on Korean newspaper

\section{INTRODUCTION}

Language is tied to linguistics where linguistics is the scientific study of language. Linguistics has several studies, one of which is Semantic that focuses on meaning as an object of study. One among several aspects which are analysed in the field of Semantics is ambiguity. In composing sentences or discourse, the choice of diction or word is very important to avoid certain sentences or discourses which may containing ambiguous meaning. The purpose in doing so is so that the reader would not misunderstand the meaning of the sentence or discourse. Ambiguous sentences are sentences that have multiple meanings in the sentence. Ambiguity in a sentence might cause the conversation to be misinterpreted or even unintelligible in terms of the essence or purpose of the sentence itself. Kim Woo-jung (2009) in his thesis entitled "A Study of Instructional Method for Ambiguity of Korean Language" states that "Lexical Ambiguity derives from the vocabulary used in the sentences, mostly due to homophones and polysemy". The research itself focuses on the discovery of ambiguous words of various types in learning material. The types of ambiguity in this study are lexical ambiguity, syntactic ambiguity, metaphorical ambiguity and pragmatic ambiguity. In his research, it is also discussed clearly regarding the types of ambiguity in Korean along with the examples of learning material as objects of his research. Novena (2015) discusses two types of lexical ambiguity: local ambiguity of 30 data $(85.7 \%)$ and global ambiguity of 5 data $(14.3 \%)$. As for the cause of the local ambiguity, she believes is due to the usage of polysemy and homonymy while the cause of global ambiguity is due to the sentence structure used in The Jakarta Post newspaper articles. Furthermore, Irianto's research (2016) shows that 1) local-level ambiguity 2) lexical ambiguity found in the data occurs at the level of words, phrases, and sentence. 3) the cause behind the lexical ambiguity is believed to be the use of polysemy, homonymy, wordplay or idioms, and slang. In addition, Puspitasari and Sutjiati (2019) discusses the lexical and structural ambiguities that occur in the article and explains the causative factors in each ambiguity. The result of the study suggests that there are 
20 ambiguous phrases and/or sentences which are found in 19 articles in The Jakarta Post that consists of 8 cases of lexical ambiguity and 12 cases of structural ambiguity. The results found a factor causing each ambiguity as well, there were 8 lexical ambiguities caused by polysemy and 12 structural ambiguities caused by equivocal phrases.

Furthermore, Khoshkhabar and Iraji (2015) identify and introduce ambiguous sentences used on the social pages of the newspaper. Based on the results of this study, structural ambiguity is the most in number in the case of type of ambiguity that can be found in the context of Iran's news media. Contrary to previous research, another study examines ambiguity in general The study by Rekha (2014) discusses ambiguity found in English books Passport to the World 2. The results of this study indicate that (1) there are four types of ambiguity, namely: lexical ambiguity, referential ambiguity, surface structure ambiguity, and deep structural ambiguity, (2) the frequency of each type of ambiguity are 73 lexical ambiguity (64.03\%), 25 referential ambiguities (21.93\%), 15 surface structure ambiguities (13.16\%) and 1 inner structure ambiguity $(0.88 \%)$, (3) the dominant type of ambiguity is lexical ambiguity, which is 73 ambiguous sentences or 64 , $03 \%$, (4) the cause of these are ambiguity without context, ambiguous word order, incorrect or nonexistent punctuation, and incorrect sentence structure, (5) the misinterpretation of these ambiguities are caused by the use of paraphrases, principle dependent sentences, adding prepositions, transferring sentences, adding additional context, adding correct punctuation and using images.

The absence of a specific research that examines Korean language objects regarding lexical ambiguity, especially in the Haninpost Newspaper advertisement, creates a gap for researchers to analyse whether the lexical ambiguity and the cause of ambiguity which arise in the study object are similar in terms of characteristics with the results of previous research. Thus, the writer aims to answer several formulated questions for the research which are "What lexical ambiguity is contained in Haninpost newspaper advertisements", "What is the meaning contained in lexical ambiguity" and "What is the causes of lexical ambiguity in Haninpost newspaper advertisements". Based on the formulation of this problem, the purpose of this study was to determine the lexical ambiguity of the Haninpost Newspaper adverts, the meaning contained in the ambiguity, and the cause of the lexical ambiguity in the Haninpost newspaper advertisement.

\section{METHODS}

This research employs qualitative approach and descriptive method. In this case, the research was carried out through documentation. The method used to focus on one object is lexical ambiguity in a sentence in a Korean newspaper advertisement. The data source in this study was 11 editions of Haninpost newspaper with 44 pieces of data as the research data. The data was also taken randomly from various editions and was not determined by the number or date of publication of the newspaper. The data collection techniques used in this study are literature study and data analysis with the analysis model that was coined by Miles \& Huberman (1984), namely data collection, data reduction, data presentation, drawing conclusions and verification.

\section{FINDINGS AND DISCUSSION}

\subsection{Lexical Ambiguity in Haninpost Newspaper Advertising}

The result of this study found that there are 19 consumer advertisements, 11 interbusiness advertisements, 1 trading advertisement, 1 recruitment advertisement, and 12 other advertisements (the other advertisements here mean those which are not included in the classification of advertisement types according to Jefkins (1996)) in Haninpost Newspaper advertisements. In addition, there are 28 advertisements which contain lexical ambiguity with the details in Table 1. 
Table 1. Data Based on Classification of Advertisement Types which Contain Lexical Ambiguity in Haninpost Newspapers

\begin{tabular}{llllll}
\hline No. & $\begin{array}{l}\text { Classification based on } \\
\text { Advertisement Types }\end{array}$ & Count & Percentage & $\begin{array}{l}\text { Lexical } \\
\text { Ambiguity }\end{array}$ & $\begin{array}{l}\text { Percentage of Lexical } \\
\text { Ambiguity based on } \\
\text { Advertisement Type }\end{array}$ \\
\hline 1. & Consumer Ads & 19 & $43,18 \%$ & 5 & $26,31 \%$ \\
2. & Inter-business Ads & 11 & $25 \%$ & 2 & $18,18 \%$ \\
3. & Commerce Ads & 1 & $2,27 \%$ & 1 & $100 \%$ \\
4. & Retail Ads & - & - & - & - \\
5. & Finance Ads & - & - & - & - \\
6. & Recruitment Ads & 1 & $2,27 \%$ & - & $33,4 \%$ \\
7. & Others & 12 & $27,27 \%$ & 4 & - \\
Total & & 44 & $100 \%$ & 12 & - \\
\multicolumn{2}{l}{ Percentage } & $100 \%$ & - & $27,27 \%$ & - \\
\hline
\end{tabular}

\subsubsection{Consumer Ads}

There are 19 ads which are categorized as consumer ads, but after the process of reduction was employed, there are only five consumer ads that contain lexical ambiguity. The following are two examples of consumer ads that contain lexical ambiguity:

\section{1) 청기와가 맛을 보장하는 불갈비 오늘 메뉴로 어떠세요?}

'how about the grilled ribs menu with a guaranteed taste Chunggiwa for today?'

On the ads above, the word 맛 /mat/ according to $\mathbf{S t}$ andard Korean Language Dictionary means 'taste (of food), satisfaction, feeling (of experience)'. The word $h$ as three different meanings but comes from the same ent ry, specifically noun. In addition, there is also a relation ship between these meanings. Then, the word 불 $/ \mathrm{bul} /$ in 불갈비 also contains ambiguity. According to Standar d Korean Language Dictionary the meanings of the $\mathrm{w}$ ord 불/bul/ are as follow:

a) Substances which burn with oxygen and produc e light and heat at high temperatures

Example. 가랑잎이 불에 타다. /garangipi bure ta $d a /$ 'smoldering leaves'

b) Fire fire'

Example. 불을 지르다. /bureul jireuda/ 'Set (on)

c) Objects that illuminate darkness by emitting light

Example. 불을 밝히다. Ibureul balkhida/ 'light (something) up' d) A metaphorical word for pouring out passion or emotion like a burning fire

Example. 그들의 사랑에 불이 붙었다. /geudeulre sarange buri buteottda/ 'Their love is on fire'

When translated into English, the sentence in the advertisement can be translated as follows:

a) How about today with the burnt ribs that guarantees the taste of Chunggiwa?

b) How about today's fire rib menu that guarantees the taste of Chunggiwa?

c) How about today with the ribs menu that guarantees the taste of Chunggiwa?

d) How about today's fiery rib menu that guarantees a taste of Chunggiwa?

According to the meanings above, the intended mea ning of the word '불' /bul/ in '불갈비' /bulgalbi/ on the ads is intended to be meant as the first and the fourth ex planation simultaneously. Thus, the word 불갈비 / bulga $\mathrm{lbi} / \mathrm{can}$ also be concluded as '불에 굽는 갈비' /bure gu pneun galbi/ 'grilled ribs' as well as 'hot and spicy ribs'. The words come from the same entry as well._Thus, it c an be concluded that the presence of the words '맛' /mat / and '불' /bul/ contain several kinds of meanings, and o $\mathrm{n}$ the case of the ad above, the lexical ambiguity is cause d by polysemy. In addition, as stated by Ullmann (1972) , ambiguity that occurs in a certain part of a sentence, no $t$ in the whole sentence, is included in local ambiguity. I $\mathrm{n}$ this case, the ad has the word '불' / bul / which has mo re than one meaning, causing ambiguity. So it can be co ncluded that the advertisement is a local ambiguity.

2) 단, 한권이라도 3 일내에 보내드립니다. 
'only (one), even though only one (our) coupon will send within 3 days.'

On the ads above, there is a lexical ambiguity in the word 단 /dan/ which according to the Standard

Korean Language Dictionary, this word can be used as an adverb as well as adjective with the following explanation:

a) Adverb: additional word used when an exception or condition is added to the previous word.

Example.

근무 시간은 오후 6 시까지로 한다. 단, 토요일은 12 시까지로 한다. 'The working hour is due until 6 PM. However, it is due until 12 o'clock on Saturday.'

b) Adjectives: words that show only one.

Example.

광호는 흉부에 단 한 발의 총탄을 맞아 절명한 것이었다. 'Gwangho was cut off by only one shot at the chest.'

However, the comma after the word '단' /dan/ on the ad above means 'having an exception or send packages even if only 'one', thus, making it ambiguous. In addition, as an adverb whether the word in the sentence serves to reinforce the meaning of 오직 한 권이라도 반드시 배송한다' 'although only one, (it) will be delivered', or as an adjective (관형사) reinforcing '한 권 일지라도' 'although only one'. So, the expression here is ambiguous. Therefore, the use of the phrase in the advertisement contains lexical ambiguity caused by homonymy. As stated by Ullmann (1972), ambiguity that occurs throughout a sentence can have more than one interpretation is called global ambiguity.

Based on the discussion of the two consumer advertisements above, it can be concluded that the Haninpost newspaper consumer advertisements contain lexical ambiguity caused by polysemy and homonymy.

\subsubsection{Inter-business Ads}

There are eleven ads which are categorized as interbusiness ads, but after the process of reduction was employed, there are only two inter-business ads that contain lexical ambiguity. The following are two examples of inter-business ads that contain lexical ambiguity:
코윈 인도네시아 학부모 강좌

\section{입학사정관계 따라잡기 \\ 'Corwin Indonesia parent course' \\ 'chasing after school connection'}

When translated into English, the sentence in the advertisement can be translated as follows:

a) Corwin Indonesia parent course Chasing relationships with school attendance

b) Corwin Indonesia parent course Catch up with the circumstances of going to school

On the second row, the word 따라잡기 /ttarajapgi/ is rooted in 따라잡다 /ttajapdal. According to Standard Korean Language Dictionary, this verb consists of two meanings in its usage. The first usage in the context of 'road' for example: 거리를 따라잡다 Igeorireul ttarajapgi/ which means 'following the road'. In addition, in the context of 'skill and level' for example: 능력. 수준 등을 따라잡다 Ineungnyeok.sujun deungeul ttarajapgi/ which means 'catching up the ability, level and others'. Simply put, this word means 'to overtake; catch up; sneak'. The ads above show the existence of several different meanings in one word, the lack of clarity of the meaning, the use of the word in advertisements, coming from the same dictionary entry, and the lexical ambiguity in the advertising is caused by polysemy. There is more than one meaning in the word 따라 잡기 / ttarajapgi /, therefore the advertisement is included in local ambiguity because the ambiguity occurs in a certain part of a sentence, not in the whole sentence like what Ullmann (1972) said.

Based on the discussion on inter-business advertising above, it can be concluded that interbusiness advertising in the Haninpost newspaper advertisement contains lexical ambiguity caused by polysemy.

\subsubsection{Commerce Ads}

There is only one advertisement that categorized as commerce ad. The following is a discussion of commercial advertising:

$$
\begin{aligned}
& \text { 일시적 효과에 그치는 코팅제가 아닙니다. } \\
& \text { 엔진의 마모부위를 살리는 치료제입니다. }
\end{aligned}
$$


자동차, 승용차, 트럭, 버스, 농기계, 발전기,

사출기, 포크레인, 오일사용하는 모든엔진 산업용기계. $\mathrm{ECO}$ SAVER TEC 최첨단 엔진오일 보강제

'this is not just a temporary effect. This is a medicine that saves engine thirst parts. Automated cars, automatic cars, trucks, buses, agricultural machinery, generators, injection machines, fork cranes, all industrial machines use oil. Advanced engine strengthening oil ECO SAVER TEC.'

When translated into English, the sentence in the advertisement can be translated as follows:

a) This is not just a temporary effect It is a drug that starts (saves) the thirsty part of the engine.

Automatic cars, automatic cars, trucks, buses, agricultural machinery, generators, injection machines, fork cranes, all industrial machines use oil. reinforcement. ECO SAVER TEC advanced engine oil

b) This is not just a temporary effect It is a drug that keeps the thirsty parts of the engine alive.

Automatic cars, automatic cars, trucks, buses, agricultural machinery, generators, injection machines, fork cranes, all industrial machines use oil. reinforcement.

ECO SAVER TEC advanced engine oil

c) This is not just a temporary effect It is a medicine that resuscitates (a person) from fainting from the thirsty engine part.

Automatic cars, automatic cars, trucks, buses, agricultural machinery, generators, injection machines, fork cranes, all industrial machines use oil. ECO SAVER TEC advanced engine oil reinforcement.

d) This is not just a temporary effect This is a drug that is used for engine thirst.

Automatic cars, automatic cars, trucks, buses, agricultural machinery, generators, injection machines, fork cranes, all industrial machines use oil. ECO SAVER TEC advanced engine oil reinforcement.
On both sentences of the ad above, there is the word 살리는 /sallineun/ which rooted in 살리다 /sallida/ according to Standard Korean Language Dictionary the word means 'saving', 'surviving', 'Waking (someone) up from fainting', 'sobering (someone) up. Even though the word has the same form, but the meaning is different. This word, however, still has a relationship with each other and comes from the same dictionary entry. So it can be said that the sentence above contains lexical ambiguity caused by polysemy. The advertisement above is also categorized as local ambiguity because the word 살리다 / sallida / has more than one meaning, causing ambiguity. As stated by Ullmann (1972) that local ambiguity occurs in certain parts of a sentence, not in the whole sentence.

Based on the discussion of the commercial advertisements above, it can be concluded that the commercial advertisements in the Haninpost newspaper advertisements contain lexical ambiguity caused by polysemy.

\subsubsection{Other Type of Ads}

There are twelve advertisements which are categorized as other type of ads. However, after the process of reduction was conducted, there are 9 ads that contain lexical ambiguity. The following are several examples of other type of ads that contain lexical ambiguity:

$$
\begin{aligned}
& \text { 유아 여름 프로그램 } \\
& \text { 재미+도전 } \\
& \text { 어린이를 위한 활동 } \\
& \text { 'Children's summer program' } \\
& \text { 'Interests + challenges' } \\
& \text { 'Activities for children' }
\end{aligned}
$$

When translated into English, the sentence in the advertisement can be translated as follows:

a) Children's summer program Interests (excitement) + Challenges Activities for children

b) Children's summer program Life (news) + Challenges Activities for children

c) Children's summer program Good experience + Challenges Activities for children 
Table 2. The Cause of Lexical Ambiguity on Haninpost Newspaper Advertisements

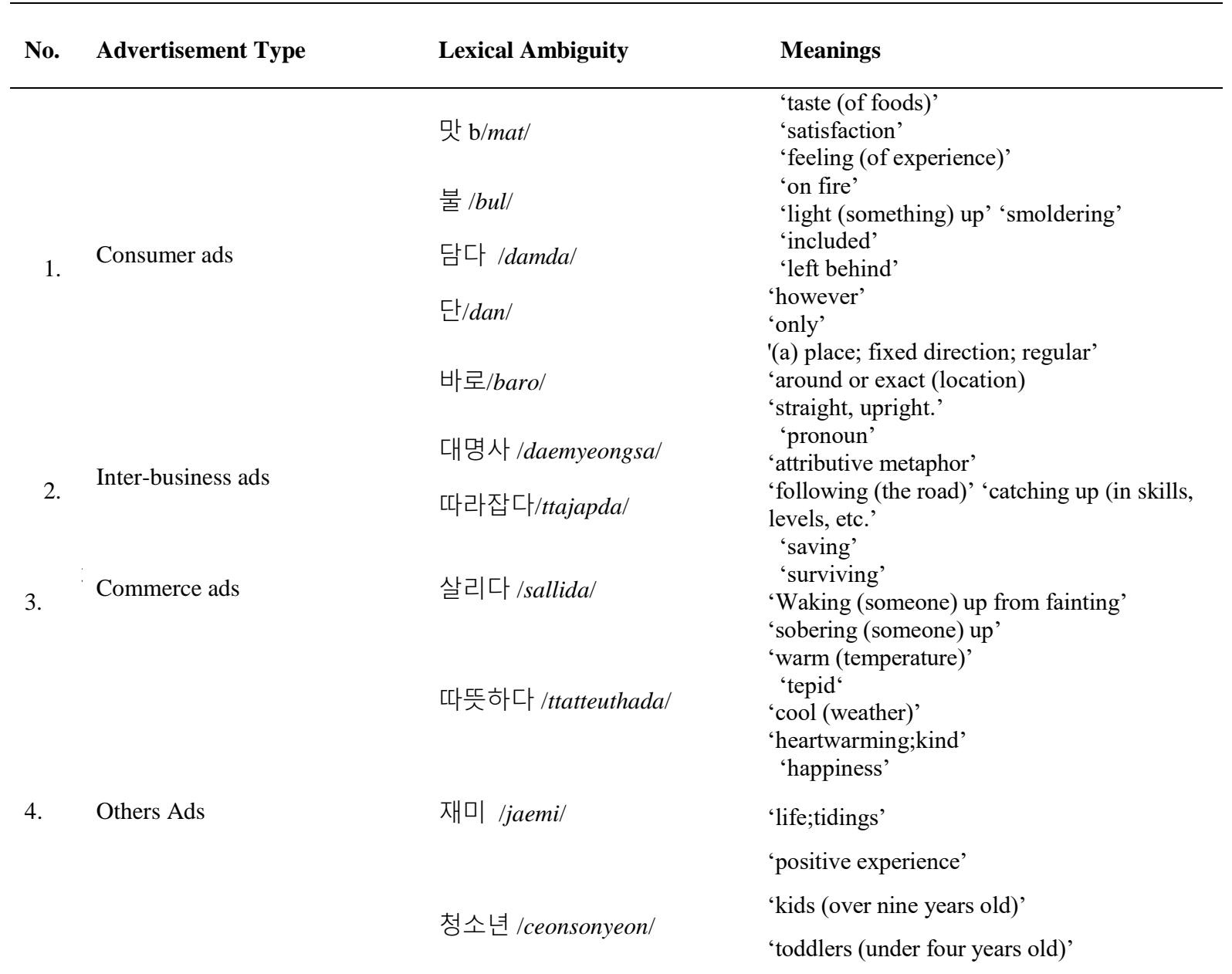

The ad above is intended for parents. This advertisement offers an activity with a program for children in summer. It can be said that this ad is quite interesting. However, the program in this activity was not explained at all, thus, making the advertisements ambiguous. The word 재미 /jaemi/ is a noun and according to Standard Korean Language Dictionary means 'excitement'. It is also the utterance mentioned when asking about 'life; tidings'. The next meaning is 'positive experience'. The form of the word does not change at all but has different meanings and comes from the same entry so that lexical ambiguity is caused by polysemy. Based on the explanation, the advertisement contained lexical ambiguity and is caused by polysemy. So that the ad above contains lexical ambiguity and includes local ambiguity. As stated by Ullmann (1972), local ambiguity is an ambiguity that occurs in a certain part of a sentence, not in the whole sentence.

Based on the discussion of the other type of advertisements above, it can be concluded that the other type of advertisements in the Haninpost newspaper contain lexical ambiguity caused by polysemy.

\subsection{Lexical Ambiguities in Haninpost Newspaper Ads and their Meanings}

\subsection{The Causes of Meaning of Lexical Ambiguity in Haninpost Newspaper Ads}

Lexical ambiguity does not occur spontaneously. Chaer (1990) distinguishes ambiguity and polysemy. He believes that polysemy occurs at the word level while ambiguity occurs at the level of order of phrases and sentences. In contrast to the opinion of Huford (1984) who argues that "lexical ambiguity depends on homonymy (senses not related) and polysemy (sense related)" (p. 137). It can be concluded that ambiguity is caused by homonymy and polysemy. Parera (2004) revealed that polysemy is a unit of speech whereas the form of words has different meanings, but there are still relationships and links between different them. On the other hand, homonymy consists of two different words written and pronounced the same, in line with Saeed's (1997) opinion "homonyms are unrellated sense of the same phonological word" (p. 63). To distinguish a word 
as homonymy or polysemy, it can be viewed from the meaning contained in the word. If the meaning and interpretation between the words are strikingly different, then it is homonymy, while the meaning and interpretation in polysemy is still realtively similar.

In regards to the previous points, the discussion shows that the causes of lexical ambiguity in the Haninpost Newspaper advertisement can be concluded into the following is a table.

Table 3. The Cause of Lexical Ambiguity on Haninpost Newspaper Advertisements

\begin{tabular}{ccc}
\hline No. & Type of Ads & The Cause of Lexical Ambiguity \\
\hline 1. & Consumer ads & Polysemy and Homonymy \\
2. & Inter-business ads & Polysemy \\
3. & Commerce ads & Polysemy \\
4. & Other type of ads & Polysemy \\
\hline
\end{tabular}

\section{CONCLUSIONS}

The lexical ambiguity that exists in Haninpost newspaper advertisements consists of 12 advertisements with a total of 44 advertisements studied. In other words, the lexical ambiguity that exists in Haninpost newspaper advertisements is only $27.27 \%$. Types of advertisements in the Haninpost newspaper which contain lexical ambiguity consist of consumer advertisements with a percentage of $26.31 \%$, interbusiness advertisements $18.18 \%$, commerce advertisements $100 \%$, and other types of advertisements $33.4 \%$. In addition, the lexical ambiguity in the Haninpost newspaper advertisement consists of local ambiguity and global ambiguity. The significance of each lexical ambiguity in the Haninpost newspaper advertisement is based on 표준국어대사전 (Standard

Korean Language Dictionary). This dictionary is a Korean dictionary published by the National Institute of Korean Language which is accessed online. In addition to using the standard dictionary as a relevant source and reviewing with the appropriate theoretical study, the researcher also verifies the research with an expert in his field. In this case, an expert in Korean linguistics, a Korean lecturer in the Korean Language Education Study Program of Universitas Pendidikan Indonesia.

\section{REFERENCES}

Chaer, A. (1990). Pengantar semantik Bahasa Indonesia (1st ed). Rineka Cipta.

Han Jae Yeong. (2013). Hangukeo eohwi gyoyuk. Taehaksa.

Huford, J. R. (1984). Semantics: A course book. Cambridge University Press.
Irianto, R. I. (2016). Ambiguitas leksikal pada lirik-lirik lagu dalam album The Marshall Mathers LP 2 karya Eminem: Kajian semantik. Retrieved from https://repository.widyatama.ac.id/xmlui/handle/12 $3456789 / 7696$

Jefkins, F. W. (1996). Periklanan (Munandar Haris, Trans.). Erlangga. (Original work published 1985)

Khoshkhabar, S. G., Iraji, M. (2015). The study of ambiguity in social context of Iranian. International Journal of Advanced Research, 3(8), 1020-1027.

Kim, J. H., Lee, M. W. (2015). Hangukeohagui Ihae. UCL Inc.

Kim, W. J. (2009). A study of instructional method for ambiguity of Korean Language. [Unpublished master's thesis]. Sungshin Women's University.

Miles, M. B., \& Huberman A. M. (1984). Analisis data kualitatif. (T. R. Rohidi, Trans.). Penerbit Universitas Indonesia. (Original work published 1992)

Novena. (2015). Ambiguitas leksikal pada koran The Jakarta Post: Kajian semantis. Retrieved from https://repository.widyatama.ac.id/xmlui/handle/12 $3456789 / 5913$

Parera, J. D. (2004). Teori semantik. Erlangga.

Puspitasari, J., Beratha, S. N. L. (2019). Lexical and structural ambiguity found in articles in The Jakarta Post Daily Newspaper. Journal of Arts and Humanities, 23(1). https://doi.org/10.24843/JH.2019.v23.i01.p04

Rekha, A. (2014). Ambiguity found in 'Passport to the worlds: A fun and easy English book': Content Analysis. [Undergraduate's thesis, Universitas Muhammadiyah Surakarta]. Electronic Theses and Dissertations.

Saeed, J. I. (1997). Semantics. Blackwell Publishers.

Ullmann, S. (1972). Semantics, an introduction to the science of meaning. Basil Blackwell.

Yoon Pyeong Hyeon. (2008). Gukouimiron. Yeollak. 